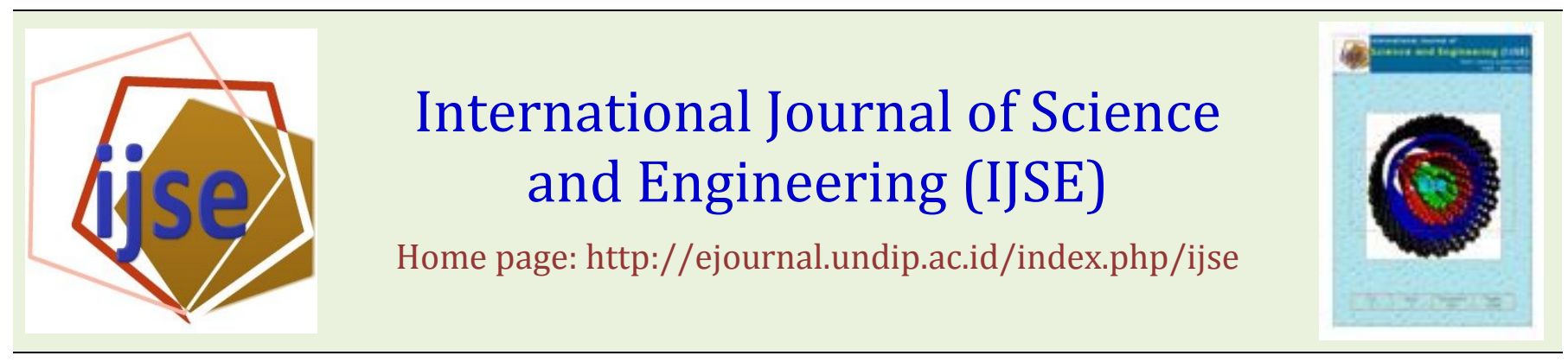

\title{
Distribution of Coral Reef and Seagrass Ecosystems's Inorganic Carbon in the Waters of Beras Basah Bontang, East Kalimantan
}

\author{
Irwan Ramadhan Ritonga1), Supriharyono²) and Boedi Henderarto ${ }^{2)}$ \\ Email: mas_dolt02@yahoo.com
}

\begin{abstract}
${ }^{1}$ Marine Sciense Department of Fisheries and Marine Science Faculty, Mulawarman University Kampus Gn. Kelua Jl.Gunung Tabur Tlp.(0541)749482 Samarinda 75119 KALTIM

${ }^{2}$ Fisheries and Marine Science Faculty of Diponegoro University, Jl. Prof. Soedarto, SH. Kampus UNDIP Tembalang Semarang 50275
\end{abstract}

\begin{abstract}
Inorganic carbon is closely related to the calcification process ( $\left.\mathrm{CaCO}_{3}\right)$, which is the main constituent of coral reefs or microorganisms that exist in the oceans such as foraminifera and cocolitoporit. Inorganic carbon is also closely linked to the chemical processes that occur when carbon dioxide gas $\left(\mathrm{CO}_{2}\right)$ dissolved in water. The research of inorganic carbon in the waters of Beras Basah was carried out in January, February and March 2012. The purpose of this study was to understand the distribution and concentration of total inorganic carbon $\left(C_{T}\right)$ in coral reef and seagrass ecosystems as well as the correlation of Beras Basah. The results showed that the concentration of total inorganic carbon $\left(C_{T}\right)$ in January average $1166.503 \mathrm{~mol} / \mathrm{kgSW}$, February average $1115.599 \mathrm{~mol} / \mathrm{kgSW}$, and then in March the average $987.443 \mathrm{~mol} / \mathrm{kgSW}$. Distribution patterns of total inorganic carbon $\left(C_{T}\right)$ is vectoral, where in January, the concentration of total inorganic carbon $\left(C_{T}\right)$ was highest in the Southeast region, was in February in the South and Southeast, while in March shifted to North region of Beras Basah Island. The concentration difference is thought to be influenced by $\mathrm{pH}$ and the seasons, tides, biochemical processes, and biological activity.
\end{abstract}

Keywords - total inorganic carbon, Beras Basah Island, ecosystem of coral reef and seagrass

Submission: April 10, $2012 \quad$ Corrected : May 20, 2013

Accepted: May 30, 2013

Doi: $10.12777 /$ ijse.5.1.1-5

[How to cite this article: Ritonga, I.R., Supriharyono, and Henderarto, B. (2013). Distribution of Coral Reef and Seagrass Ecosystems's Inorganic Carbon in the Waters of Beras Basah Bontang, East Kalimantan. International Journal of Science and Engineering, 5(1),1-6. Doi: $\underline{10.12777 / \text { ijse.5.1.1-5] }}$

\section{INTRODUCTION}

Beras Basah aquatic ecosystems that are located in Bontang coastal area is highly vulnerable to climate change caused by global warming process of the carbon dioxide $\left(\mathrm{CO}_{2}\right)$ emissions from land use change, forest fires, fossil fuels (oil and coal), respiration, decomposition of organic matter. One of the media to reduce the amount of carbon dioxide in the atmosphere is the process of absorption of carbon dioxide by plants and organisms through photosynthesis and respiration chlorophyll in the ocean. With the influence of the $\mathrm{CO}_{2}$ absorption process, it will affect the quality of waters that have Beras Basah marine potentials are quite good especially coral reefs and seagrass ecosystems, one of which is the process of calcification which ties carbonate ion $\left(\mathrm{CO}_{3}{ }^{2-}\right)$ and bicarbonate ions $\left(\mathrm{HCO}_{3}^{-}\right)$as the main constituent of coral stone (Marubini et al., 2003).

In the process of calcification, many benefits that science can be assessed as to how the pattern of distribution, the amount of inorganic carbon, the level of closeness (correlation) that occur in coral and seagrass ecosystems by station and time, as well as determine the level of closeness (correlation) of several parameters forming total inorganic carbon $\left(\mathrm{C}_{\mathrm{T}}\right)$ in the waters, as the research that has been conducted by Suratno and Prayuda (2010) and Afdal et al (2011) in the waters of Java. The conclusions from these studies that distibusi inorganic carbon in waters affected by seasonality and supply of biochemical processes, and marine biological activity. 
Based on this, we need some research on inorganic carbon in the water Wet Rice, because previously there was no detailed information to determine the inorganic carbon in the East Kalimantan region especially Bontang.

Therefore as for the formulation of the problem in this study, namely how to assess and analyses the pattern of distribution of total inorganic carbon $\left(\mathrm{C}_{\mathrm{T}}\right)$ in coral reef and seagrass ecosystems, how many total inorganic carbon $\left(\mathrm{C}_{\mathrm{T}}\right)$ on coral and seagrass ecosystems. Then determine the level of closeness (correlation) total inorganic carbon $\left(\mathrm{C}_{\mathrm{T}}\right)$ on coral and seagrass ecosystems based on habitat and time.

\section{MATERIALS AND METHODS}

\section{Research Time and Location}

This research was conducted in 3 months from January 2012 to March 2012. Research site was located in the water of Beras Basah, Bontang city in East Kalimantan province (Figure 1).

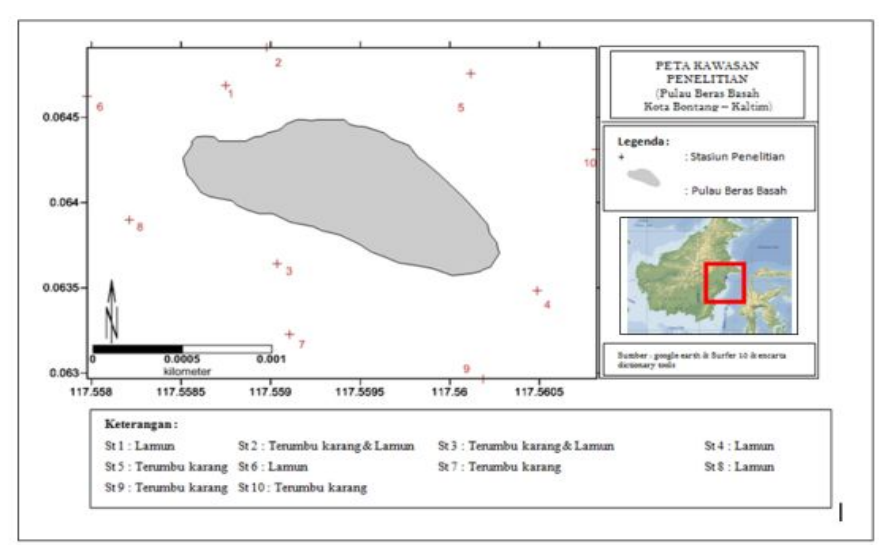

Figure 1. Location Beras Basah Research in Water

\section{Research Methods}

This research method is case study includes review of documents (literature review), field survey (ground check) and observations as well as interviews with the related parties that supporting this study. Determination of sea water sampling stations in waters Beras Basah was conducted by considering geographical area representation using purposive sampling. Stages of research begins with the measurement of water quality parameters ( $\mathrm{pH}, \mathrm{DO}$, temperature and salinity) in the early hours before sunrise (4:00 to $6: 30 \mathrm{pm}$ ) at 10 stations (zone of coral reefs, seagrass and coral reefs and seagrass shift) using Waterproof Cyber Scan PCD 650 (Eutec Instruments). $\mathrm{CO}_{2}$ parameters was done by titration method in situ, while the samples of water samples for the parameters Nitrate $\left(\mathrm{NO}_{3}\right)$, phosphor $\left(\mathrm{PO}_{4}\right)$ and Silicon $\left(\mathrm{SiO}_{2}\right)$ was taken immediately from the study site, and then analyzed in the laboratory with a spectrophotometer exsitu next day. For the determination of the value of total alkalinity $\left(\mathrm{A}_{\mathrm{T}}\right)$ samples was calculated following the method proposed by APHA (1985) by calculating the value of $\mathrm{pH}$, salinity and temperature.

After getting the value of the $\mathrm{CO}_{2}$ from the study site, then the determination of the value of the concentration of carbon dioxide $\left(\mathrm{CO}_{2}\right)$ dissolved bicarbonate ions $\left(\mathrm{CO}_{3}{ }^{2-}\right)$ and carbonate ions $\left(\mathrm{HCO}_{3}^{-}\right)$was calculated using $\mathrm{CO}_{2}$ Calc program (Robbins at. al., 2010) parameters of the first and second dissociation constants (K1 and K2) of carbonic acid (Lueker et. al., 2000; Millero, 2010), $\mathrm{KHSO}_{4}$ (Dickson, 1990b), the pH scale [scale Seawater, (mol / kg SW)], water - Sea Flux: Ho et. al., 2006) with the formula:

$$
\mathrm{C}_{\mathrm{T}}=\left[\mathrm{CO}_{2}^{*}\right]+\left[\mathrm{HCO}_{3}^{-}\right]+\left[\mathrm{CO}_{3}^{2-}\right]
$$

Parentheses is the total concentration of a solution $(\mathrm{mol} / \mathrm{kg})$ and $\left[\mathrm{CO}_{2}{ }^{*}\right]$ is the total carbon dioxide concentration, $\left[\mathrm{HCO}_{3}^{-}\right]$is carbonic acid $\left[\mathrm{CO}_{3}^{2-}\right]$ is the carbonate ion. In this case the unit used is mol / kg SW.

Inorganic carbon analysis results, conducted further tests to determine whether there is a correlation between the parameters of the Pearson test using SPSS 17 software. Then to determine the pattern of distribution of inorganic carbon in the water a few stations Wet Rice spatially adjacent to each other, then using software Surfer 10.

\section{Types and Sources of Data}

The data required in this study include primary and secondary data. The basic data are sea surface temperature; sea surface current speed and direction of ocean surface currents Chemical parameters include carbon dioxide $\left(\mathrm{CO}_{2}\right)$, alkalinity, $\mathrm{pH}$, dissolved oxygen (DO), salinity, nitrate, phosphate and silicon. While secondary data required is drawing water Wet Rice geo-processing results that have digital format is the result of recording in 2009.

\section{RESULTS AND DISCUSSION}

\section{Distribution of Inorganic Carbon}

Dissolved $\mathrm{CO}_{2}$ (Dissolved $\mathrm{CO}_{2}$ ) Based on the analysis, the concentration of dissolved $\mathrm{CO}_{2}$ in the waters of Beras Basah in January between 10.553 to $36.535 \mathrm{~mol} / \mathrm{kg} \mathrm{SW}$ with an average of $24.467 \mathrm{~mol} / \mathrm{kg} \mathrm{SW}$, while in February between 7.795 to $17.838 \mathrm{~mol} / \mathrm{kg} \mathrm{SW}$ with average of $12.579 \mathrm{~mol} / \mathrm{kg} \mathrm{SW}$, then in March between 6.556 to $15.891 \mathrm{~mol} / \mathrm{kg} \mathrm{SW}$ with average $10.402 \mathrm{~mol} / \mathrm{kg} \mathrm{SW}$. In general, the distribution of $\mathrm{CO}_{2}$ dissolved in January is higher than the $\mathrm{CO}_{2}$ dissolved in February and March (Figure 2). Cause of the high concentration of $\mathrm{CO}_{2}$ dissolved in the waters of Beras Basah is caused by several factors, the first one is still good and the preservation of coral reefs and seagrass ecosystems in the waters of both the Beras Basah 30.42336 ha (Government of Bontang, 2008). With both still and subdued coral reef and seagrass ecosystems, then the process of respiration occur will run well. Bakker et al., 1996 and Sanusi (2009) argues that the rise and fall of levels of carbon dioxide $\left(\mathrm{CO}_{2}\right)$ in the ocean caused by several things, namely: respiration and photosynthesis activity of phytoplankton and aquatic biota and organic matter degradation activity.

\section{Bicarbonate ions $\left(\mathrm{HCO}_{3}^{-}\right)$}

Based on the analysis of the bicarbonate ion $\left(\mathrm{HCO}_{3}^{-}\right)$ which has been performed at each station between the months of January to March in the waters of Beras Basah Island, $\mathrm{HCO}_{3}{ }^{-}$concentration in January between 1007.773 
to $1176.814 \mathrm{~mol} / \mathrm{kg} \mathrm{SW}$ with an average of 1096.380 mol/ kg SW, in February between 949.915 to 1085.416 $\mathrm{mol} / \mathrm{kg} \mathrm{SW}$ with an average of $1029.8032 \mathrm{~mol} / \mathrm{kg} \mathrm{SW}$, then in March between 797.412 to $968.664 \mathrm{~mol} / \mathrm{kg} \mathrm{SW}$ with average $908.508 \mathrm{~mol} / \mathrm{kg} \mathrm{SW}$.

In general, the distribution of $\mathrm{HCO}_{3}^{-}$was higher in January than in February and March. As for the causes of the high $\mathrm{HCO}_{3}-$ waters Beras Basah Island one of which is caused by high concentrations of total alkalinity $\left(\mathrm{A}_{\mathrm{T}}\right)$ in the waters. In addition to the high total alkalinity $\left(A_{T}\right)$, the formation of the concentration of bicarbonate $\left(\mathrm{HCO}_{3}^{-}\right)$is closely connected with the release of $\mathrm{H}^{+}$ions and acceptance happens to carbonic acid $\left(\mathrm{H}_{2} \mathrm{CO}_{3}\right)$ to $\mathrm{HCO}_{3}{ }^{-}$and $\mathrm{H}^{+}$are reversible. Wibisono (2005), that sea water is able to accept and release protons are indicated with components bicarbonate $\left(\mathrm{HCO}_{3}^{-}\right)$, carbonate ion $\left(\mathrm{CO}_{3}{ }^{2-}\right)$ and hydroxide $\left(\mathrm{OH}^{-}\right)$. Thus, the ability of a system of "self defense" against acidification or buffer system of a solution (Cai et al., 2006; Royal Society, 2005; Wibisono, 2005).

\section{Carbonate ion $\left(\mathrm{CO}_{3}{ }^{2-}\right)$}

Based on the analysis, carbonate ion $\left(\mathrm{CO}_{3}^{2-}\right)$ in January between 28.405 to $78.937 \mathrm{~mol} / \mathrm{kg} \mathrm{SW}$ with an average of $46.665 \mathrm{~mol} / \mathrm{kg} \mathrm{SW}$, while in February between 54.605 to $96.050 \mathrm{~mol} / \mathrm{kg} \mathrm{SW}$ with an average of $73.217 \mathrm{~mol} / \mathrm{kg}$ SW, then the March between 48.914 to $88.735 \mathrm{~mol} / \mathrm{kg}$ SW with average $68.533 \mathrm{~mol} / \mathrm{kg} \mathrm{SW}$. In general, the distribution of $\mathrm{CO}_{3}{ }^{2-}$ is higher in February than in March and January.

As for the cause of the high distribution of $\mathrm{CO}_{3}{ }^{2-}$ is also likely due to the high $\mathrm{pH}$ value and dissolved $\mathrm{CO}_{2}$ in other stations. Langdon et al. (2000) and Marubini et al. (2003) that the $\mathrm{CO}_{3}{ }^{2-}$ is the main compound-forming corals in addition to $\mathrm{Ca}^{2+}$ ions, the two compounds will bind to form a compound $\mathrm{CaCO}_{3} \cdot \mathrm{CO}_{3}{ }^{2-}$ ion is closely related to the $\mathrm{pH}$, if the $\mathrm{pH}$ drops, the number of $\mathrm{CO}_{3}{ }^{2-}$ ion is also reduced, and vice versa, if the $\mathrm{pH}$ rises, the number of $\mathrm{CO}_{3}{ }^{2-}$ ions also increases. With increasing ion $\mathrm{CO}_{3}{ }^{2-}$ is it will cause the rock - forming coral reef ecosystems will be better in the waters of Beras Basah.

\section{Total Inorganic Carbon (CT)}

Based on the statistical analysis of total inorganic carbon in the waters of Beras Basah, the range of total inorganic carbon concentration $\left(\mathrm{C}_{\mathrm{T}}\right)$ in the month of January between 1097.263 to $1244.465 \mathrm{~mol} / \mathrm{kg} \mathrm{SW}$ with an average of $1166.503 \mathrm{~mol} / \mathrm{kg} \mathrm{SW}$, in February between 1053.760 to $1168.781 \mathrm{~mol} / \mathrm{kg}$ SW with an average of $1115.599 \mathrm{~mol} / \mathrm{kg} \mathrm{SW}$, then in March between 884.310 to $1033.468 \mathrm{~mol} / \mathrm{kg} \mathrm{SW}$ with - average $987.443 \mathrm{~mol} /$ kg SW.

In general, the value of total inorganic carbon $\left(\mathrm{C}_{\mathrm{T}}\right)$ in January generally (average) higher when compared with February and March. Distribution of total inorganic carbon $\left(\mathrm{C}_{\mathrm{T}}\right)$ as measured in January, February and March have a different spatial patterns (Figure 2). Where in January, total inorganic carbon $\left(\mathrm{C}_{\mathrm{T}}\right)$ is the highest in the southeast. In February, total inorganic carbon $\left(\mathrm{C}_{\mathrm{T}}\right)$ is the highest in the south-east and south. Then in March, total inorganic carbon $\left(\mathrm{C}_{\mathrm{T}}\right)$ is the highest in the North Island of Beras Basah. The cause of the high total inorganic carbon $\left(\mathrm{C}_{\mathrm{T}}\right)$ in January caused in part by the low $\mathrm{pH}$, seasonal factors, tides, biochemistry process and biological activity (biological pump). Parson and Takahashi (1977) and Goyet et al. (1998) suggested that the presence of the process of diffusion, advection, and mixing of water masses, nutrients that are in the base layer can be lifted to the surface and can be used by organisms in the water. Total Inorganic Carbon $\left(\mathrm{C}_{\mathrm{T}}\right)$ on Coral Reef and Seagrass Ecosystems based on habitat and time (Table 1).

The influence of the time factor to the total inorganic carbon $\left(\mathrm{C}_{\mathrm{T}}\right)$ in the waters of Beras Basah is most likely caused by the influence of the season in the form of wind speed, surface currents, tides, and others - others that could lead to changes in $\mathrm{pH}$, biochemical and biological activity in these waters. Nevertheless, the influence of the time factor to the total inorganic carbon $\left(\mathrm{C}_{\mathrm{T}}\right)$ can not be ignored, the effect of time also gives effect to the presence of total inorganic carbon $\left(\mathrm{C}_{\mathrm{T}}\right)$ in waters although not significant $(p=0,697)$.

With the dynamic nature of the sea, coupled with climate change is occurring, potentially will drive physics and chemistry changes result in changes in the composition and ecosystem contained in these waters. Accordingly, the seasonal factors are the most important factors that influence the presence of total inorganic carbon $\left(\mathrm{C}_{\mathrm{T}}\right)$ in the waters of Beras Basah. This result is in line with the finding of (Romimohtarto and Juwana, 2009; Gupta et al., 2008; Borges, 2011) which suggests that the marine environment is always dynamic, sometimes these environmental changes are slow and fast in changing. Fast or slow pace of change was the same influence, i.e., both the nature of these changes will alter the intensity of factors environmental factors (water movement, temperature, salinity, and light).

Table 1. The Influence of Time Factor to Total Inorganic Carbon $\left(\mathrm{C}_{\mathrm{T}}\right)$

\begin{tabular}{lrrrr}
\hline \multirow{2}{*}{ Habitat } & \multicolumn{4}{c}{ Total Inorganic } \\
& \multicolumn{4}{c}{ Carbon ( mol/kg SW) } \\
\cline { 2 - 5 } Coral Reef & 5 & 1183.295 & 1115.341 & 1021.788 \\
& 7 & 1110.715 & 1157.686 & 970.506 \\
& & & & \\
& 9 & 1244.465 & 1053.76 & 979.244 \\
Seagrass & 10 & 1195.175 & 1156.341 & 1016.684 \\
& 1 & 1152.1 & 1094.842 & 987.908 \\
& 4 & 1097.263 & 1102.735 & 884.31 \\
Coral Reef \& Seagrass & 6 & 1147.953 & 1081.661 & 961.869 \\
& 8 & 480.739 & 1168.781 & 990.24 \\
& 2 & 1189.834 & 1164.338 & 1033.468 \\
& 3 & 1163.497 & 1060.514 & 1028.419 \\
\hline
\end{tabular}

Source: Result process primary of data.

Seasonal factors that affect the total inorganic carbon $\left(\mathrm{C}_{\mathrm{T}}\right)$ by station and time in the waters of Beras Basah according to the results of research conducted by (Suratno and Prayuda 2010; Prihartanto, 2008; Zhai and Dai, 2009), that the distribution of inorganic carbon that occur in clusters and in Pari Island, Weir of Gunungsari and Weir of Jagir in Surabaya River is also caused by seasonal factors. 

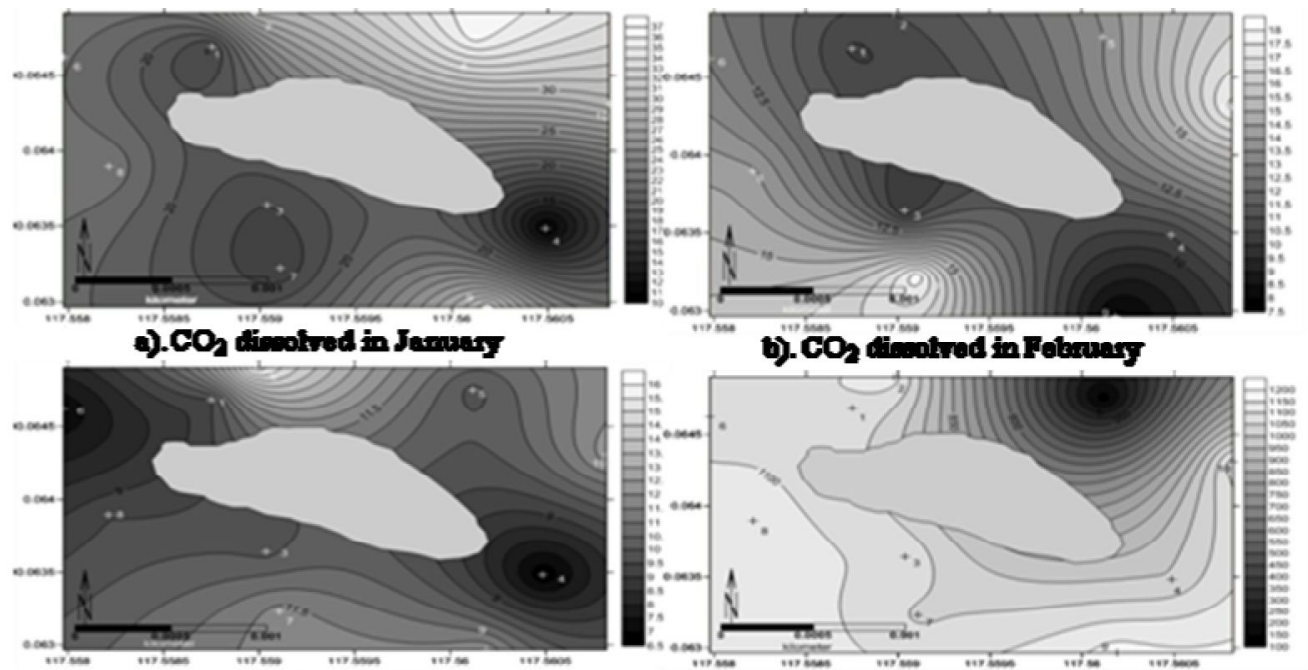

O. COS dienolvid in Manth
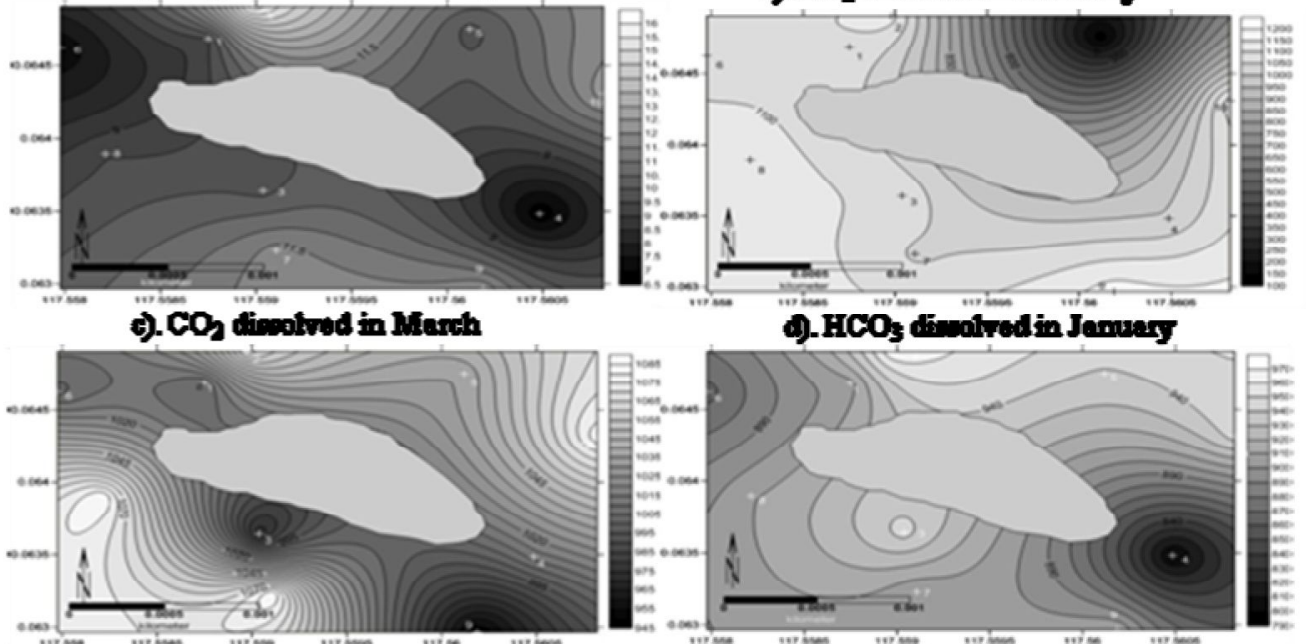

o). HCO diboolved in Fobruery
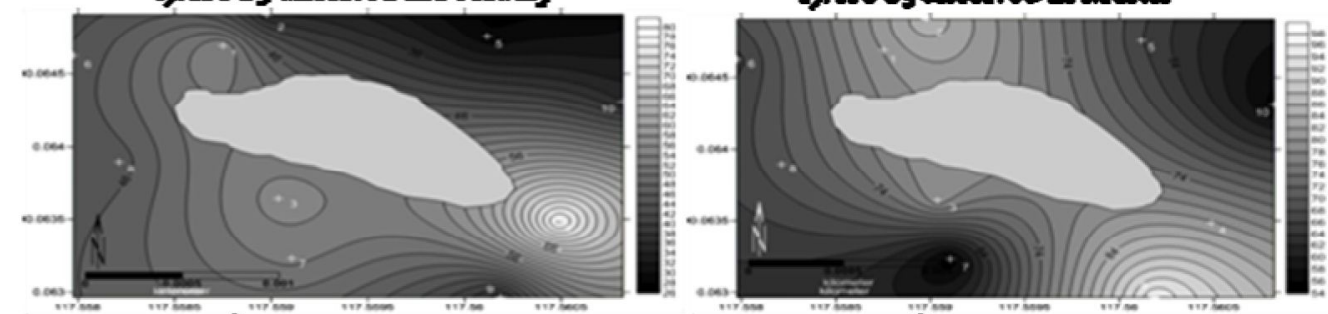

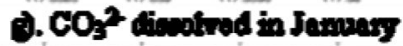
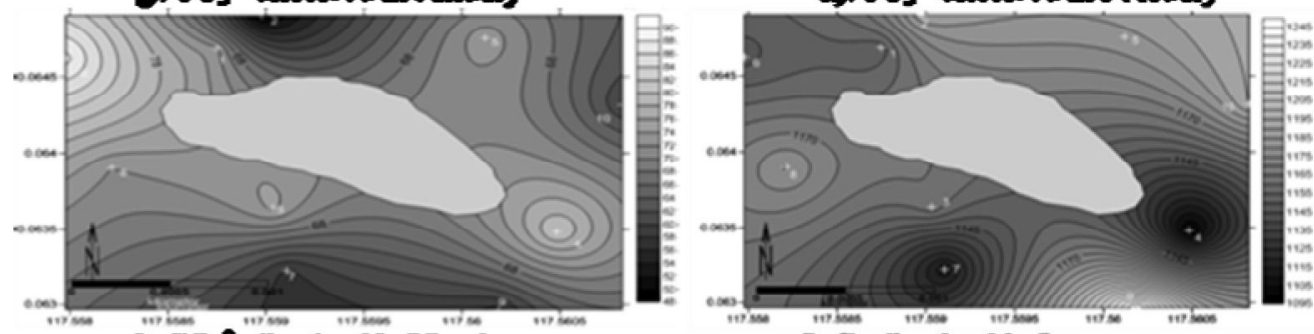

9. $\operatorname{CO}_{5}^{2}$ direoulrad in March
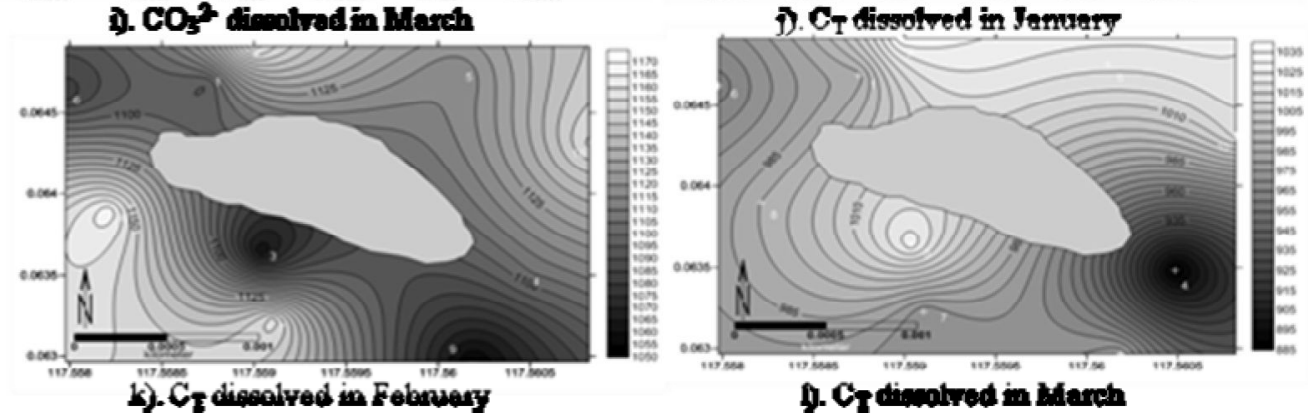

Figure 3. Distribution patterns of marine inorganic carbon Beras Basah Waters

Parameter water quality and nutrient water (nitrate, phosphate and silicate). In general, concentrations of $\mathrm{pH}$, temperature, DO, salinity and total alkalinity $\left(\mathrm{A}_{\mathrm{T}}\right)$ in January - March in the waters of Beras Basah Island still stage a safe condition for the life of the coral reef and seagrass ecosystems (KEPMEN LH No. 51 of 2004 for marine biota). 
Then the content of nitrate, phosphate was detected in the waters of Beras Basah Island when compared with the threshold value set by KEPMEN-LH No. 512004 for marine life has been exceeded for nitrate concentrations $(0.008 \mathrm{mg} / \mathrm{L})$ and phosphate $(0.015 \mathrm{mg} / \mathrm{L})$. Hence the concentration of nitrate and phosphate in the water can affect the lives feared (growth and development) biota that live in the waters of Beras Basah Island, while the presence of silicon in the waters of Beras Basah is not becoming a problem to the ecosystem in the region.

\section{Conclusions}

Distribution patterns of inorganic carbon (dissolved $\mathrm{CO}_{2}, \mathrm{HCO}_{3}{ }^{-}, \mathrm{CO}_{3}^{2-}$, and $\mathrm{C}_{\mathrm{T}}$ ) in the waters of Beras Basah in the early morning showed that the highest concentrations are in the northeast in January, February is still in the south and southeast regions, in March to move into the north. In general, inorganic carbon $\left(\mathrm{C}_{\mathrm{T}}\right)$ in January is higher when compared with February and March. Then the habitat factors greatly affect the total inorganic carbon $\left(\mathrm{C}_{\mathrm{T}}\right)$, but the time factor does not affect the total inorganic carbon $\left(\mathrm{C}_{\mathrm{T}}\right)$. Then the result of interaction between the station and the time factor was not there with influence or joint effect between the station and the time of the total inorganic carbon $\left(\mathrm{C}_{\mathrm{T}}\right)$.

\section{REFERENCES}

[1]. American Public Health Association (APHA). 1985. Standart Methods for The Examination of Water and Wastewater, 16th Edition. American Public Health Association, Washington DC. ISBN: 9780875531311.

[2]. Bakker, D.C.E., H.J.W. de Baar and H. P. J. de Wildw. 1996. Dissolved Carbon Dioxide in Ducth Coastal Waters. Marine Chenistry 55: 247 - 263. http://dx.doi.org/10.1016/S0304-4203(96)00067-9.

[3]. Borges, A.V. 2011. Present Day Carbon Dioxide Fluxes in the Coastal Ocean and Possible Feedbacks Under Global Change. Oceans and the Atmospheric Carbon Content. Springer Netherlands. ISBN: 978-90-481-9821-4. pp 47-77 pp.

[4]. Cai, W.J., M. Dai, and Y. Wang, 2006. Air - Sea Exchange of Carbon Dioxide in Ocean Margins: a Province Based Synthesis. Geophysical Research Letters 33: LI2603. http://dx.doi.org/10.1029/2006GL026219.

[5]. Dickson, A.G. 1990. Thermodynamics of the Dissociation of Boric Acid in Synthetic Seawater From 273.15 To 318.15 K: Deep Sea Research Part A, Oceanographic Research Papers. 37: 755-766. http://dx.doi.org/10. 1016/0198-0149(90)90004-F

[6]. Goverment of Bontang. 2008. Potential Study Final Report Coastal Bontang. Pemerintah Kota Bontang. Bontang.

[7]. Goyet, C., N. Metzl, F. Millero, G. Eischeild, D.W. O'Sullivan and A. Poisson 1998. Temporal Variation of the Sea Surface $\mathrm{CO}_{2}$ Carbonate Properties in the Arabian Sea. Marine Chemistry 63: 69 - 79. http://dx.doi.org/10.1016/S0304-4203(98)00051-6.

[8]. Gupta, G. V. M., V. V. S. S. Sarma, R. S. Robin, A. V. Raman, M. Jai Kumar, M. Rakesh, and B. R. Subramanian. 2008. Influence of Net Ecosystem Metabolism in Transferring Riverine Organic Carbon to Atmospheric $\mathrm{CO}_{2}$ in a Tropical Coastal Lagoon (Chilka Lake, India). $\begin{array}{llll}\text { Biogeochemistry, } & \text { 87: } 265 \quad 285.2 .\end{array}$ http://dx.doi.org/10.1007/s10533-008-9183-x.

[24]. http://dx.doi.org/10.1016/j. marchem. 2007.02.011.
[9]. Ho, D.T., C.S. Law., M.J. Smith., P. Schlosser., M. Harvey., and P. Hill. 2006. Measurements of Air - Sea Gas Exchange at High Wind Speeds in the Southern Ocean: Implications for Global Parameterizations: Geophysical Research Letters, V. 33, no. L16611. http://dx.doi.org/10. 1029/2006GL026817.

[10]. Langdon, C., T. Takahashi, C. Sweeney, D. Chipman, J. Goddard, F. Marubini, H. Aceves, H. Barnett and M. J. Atkinson 2000. Effect of Calcium Carbonate Saturation State on the Calcification Rate of an Experimental Coral Reef, Global Biogeochem. Cycles 14: 639 - 654. http://dx.doi.org/10.1029/1999GB001195

[11]. Lueker, T. J., Dickson, A.G., and Keeling, C.D., 2000. Ocean $\mathrm{pCO}_{2}$ Calculated From Dissolved Inorganic Carbon, Alkalinity, and Equations for $\mathrm{K}_{1}$ and $\mathrm{K}_{2}$ : Validation Based on Laboratory Measurements of $\mathrm{CO}_{2}$ in Gas and Seawater at Equilibrium: Marine Chemistry 70: 105 - 119. http://dx.doi.org/10.1016/S03044203(00) 00022-0.

[12]. Millero, F.J. 2010. Carbonate Constants for Estuarine Waters. Marine and Freshwater Research 61: 139 - 142. http://www.publish.csiro.au/ http://dx.doi.org/10.1071/MF09254

[13]. Marubini, F., P.C. Ferrier., and J.P. Cuif. 2003. Suppression of Skeletal Growth in Scleractinian Corals by Decreasing Ambient Carbonate-Ion Concentration: A cross-family comparison. Proc. R. Soc. London, Ser. B 270: 179-184. http://rspb.royalsocietypublishing.org/ content/270/1511/179\#related-urls. http://dx...doi.org/10.1098/rspb. 2002.2212.

[14]. Parson, T.R., and M. Takahashi., B. Harbgrave. 1984. Biological Oceanographic Processes. $3^{\text {nd }}$ edition. Pergamon Press. New York. ISBN: 0-08-030766-3, $331 \mathrm{pp}$.

[15]. Prihartanto, 2008. Debit fluctuations influence the pattern of fluctuations Carbon in Surabaya River. Jurnal Sains dan Teknologi Indonesia 10 (2): 106 - 111.

[16]. Robbins, L. L., M.E. Hansen., J.A. Kleypas., S.C. Meylan. 2010. $\mathrm{CO}_{2}$ Calc: a User. Friendly Seawater Carbon Calculatorc for Windows, Mac OSX, and I OS (I Phone): U.S. Geological Survey Open - File Report 2010 - 1280. [Download March, 7, 2013]. Available from: http://pubs.usgs.gov/of/2010/1280/. (Accessed on March 7, 2013).

[17]. Romimohtarto, K., and S. Juwana. 2009. Marine Biology: Science Marine Biology. Djambatan, Jakarta. ISBN 978-979- 428- 643- 2. 540 page.

[18]. Royal Society, 2005. Ocean Acidification Due to Increasing Atmospheric Carbon dioxide. Policy Document 12/05. The Royal Society: $\quad 1 \quad$ - 68. http://royalsociety.org/uploadedFiles/Royal_Society_ Content/policy/publications/2005/9634.pdf. (Accessed on May 12, 2013).

[19]. Sanusi, H. 2009. Marine Chemistry and Pollution. Process Chemistry and Physical Interaction with the Environment. $1^{\text {nd. }}$. Department of Marine Sciences and Technology Faculty of Fisheries and Marine Sciences Bogor Institute of Agriculture. ISBN 979-99650-0-4. 215 page.

[20]. Suratno, B. dan Prayudha. 2010. Temporal Distribution of Inorganic Carbon in Water Cluster Pari Island. Penelitian Oseanografi - LIPI. Oseanologi dan Limnologi di Indonesia 36: 165 $-180$.

[21]. Wibisono,M.S. 2005. Introduction to Marine Science. Publisher PT Gramedia Widiasarana Indonesia. Jakarta. ISBN 979-759-1557.226 page.

[22]. Zhai, W. and M. Dai, 2009. On the Seasonal Variation of Air - Sea $\mathrm{CO}_{2}$ Fluxes in the Outer Changjiang (Yangtze River) Estuary, East China Sea. Marine Chemistry 117: 2-10. http://dx.doi.org/10.1016/j. marchem.2009.02.008.

[23]. Zhai, W., M. Dai and X. Guo. 2007. Carbonate System and $\mathrm{CO}_{2}$ Degassing Fluxes in the Inner Estuary of Changjiang (Yangtze) River, China. Marine Chemistry 107: 342 - 356. 